\title{
Evaluating the performances of a flexible mechanism of water diversion: application on a northern Italy gravity-driven irrigation channel
}

\author{
Daniele Masseroni ${ }^{1} \cdot$ Alessandro Castagna $^{1} \cdot$ Claudio Gandolfi $^{1}$
}

Received: 20 June 2020 / Accepted: 23 December 2020 / Published online: 7 February 2021

(c) The Author(s) 2021

\begin{abstract}
Improving the management of irrigation schemes is a priority in the Mediterranean countries of the EU to achieve the objectives of the Water Framework Directive 2000/60EC. In the case of schemes based on open-channel networks for water conveyance and delivery, a limitation to the management efficiency is the huge number of gates that need to be controlled and regulated manually to adapt the flow to the actual irrigation water demand. Automated and coordinated gate regulation of large irrigation schemes has been successfully implemented in some areas of the world (e.g., NSW, Australia), but it implies huge public investments that are often unavailable. Opposite to this top-down approach, the Lombardy region (the largest irrigated region in the EU) has explored an approach based on funding small projects, which should demonstrate the potential of innovation in irrigation practice and foster the expansion of the most effective measures. In this paper, we analyze the effects of one of these projects, consisting in the substitution of a manual gate, controlling the supply of irrigation to a 150 ha irrigation district, with an automated, remotely controlled gate. Nine years of daily flow measurements at the district inlet, provided by the irrigation consortium that manages the gate, were compared with the rigid flow regulation that was applied when the inlet gate was manually regulated and with the irrigation water requirements simulated with a distributed agro-hydrological model widely used in the region for irrigation accounting and planning. The results show that the flexible regulation allowed by the new gate provided an average water saving of $12,000 \mathrm{~m}^{3} /$ ha/year compared to the rigid regulation system. A further, though smaller, margin of improvement of $5000 \mathrm{~m}^{3} /$ ha/year can be achieved with an optimal regulation that follows exactly the crop water requirements. A further interesting empirical evidence is that the simulation model fits very well the irrigation water requirements of the district using only easily accessible meteorological input data, without exploiting any information from ground or remote sensors to update soil moisture or crop developments during the season. This indicates that it could be effectively used, with very limited costs and effort, to support and improve the gate management. Finally, a preliminary economic analysis shows that the cost of the gate installation is sustainable, but the upscaling of this type of intervention to larger areas requires the support of public funding to cover approximately half of the cost of investment needed for the networking infrastructures.
\end{abstract}

\section{Introduction}

The conveyance and distribution of water for irrigation through open channels is the oldest and still the most widespread technique in the world for delivering water to the farms in irrigated areas (Smith et al. 2016). As a result of potential climate change impacts on water resources

Daniele Masseroni

daniele.masseroni@unimi.it

1 Department of Agricultural and Environmental Sciences, University of Milan, Via Celoria 2, 20133 Milan, Italy availability predicted by IPCC scenarios (Pachauri et al. 2014), national and local governments in many areas have promoted modernization of irrigation schemes that are often based on simply substituting traditional open-channel systems with pressurized networks (García et al. 2014). This approach, which at a first glance might appear the best solution for improving water use efficiency, has proved to trigger considerable side effects leading to a drastic increase in water costs, mainly due to the higher energy requirements (Tarjuelo et al. 2015; Perry et al. 2017). Emblematic cases occurred in Spain, as reported, for example, in García et al. (2016), who present an analysis on five irrigation districts of Andalusia indicating an average reduction in water diverted 
for irrigation of $23 \%$, but an increase in water costs of $52 \%$ : farmers were led to choose more profitable crops due to the higher water costs, and this in turn further increased the energy consumption and reduced the water savings due the higher water requirements of the new crops (Rodríguez Díaz et al. 2011).

Building on the results of these experiences, soft-path approaches based on the idea that efficiency depends to a large extent from how a system is managed and not only from the inherent characteristics of the system itself, were developed (Masseroni et al. 2017). In particular, the trinomial Measure $\times$ Model $\times$ Manage $\left(\mathrm{M}^{3}\right)$ appears a formula that might permit to shift to an "effective efficiency" concept that includes interactions among irrigation, environment, landscape and cultural heritage (Haie et al. 2008; Mateos 2008).

In this context, the application of flexible, automated regulation devices for managing irrigation at different levels (from irrigation district to individual fields) appears as a viable solution that can be exploited in many cases to increase water conveyance and distribution efficiency of open-channel networks, without altering significantly their original characteristics. Hydraulic infrastructures based on a system of automatic gates located in strategic points of the irrigation network allow to maintain optimal water levels along the length of a channels, providing more consistent and reliable flows through farm service points (Bath and Hirekhan 2015; Bonet et al. 2019; Gillies et al. 2010; Gillies and Smith 2015). One of the first and largest systems of this type has been developed during the last two decades in New South Wales (NSW, southern Australia). It combines gate synergic operations and network controls, and now represents the flagship of a group of irrigation consortia where the entire network of channel is remote-controlled and the delivery of water to farmers can be made completely ondemand (Kong et al. 2019). The system also provides the accurate, continuous and distributed measurement of water flows, which allows the precise control of the efficiency of the different irrigation network components and the application of solid criteria for the partition of costs among farmers (Khatavkar et al. 2020; Zheng et al. 2019).

The large-scale improvements of irrigation systems in NSW were funded through massive public investments to return water to the environment and to make agricultural industries more competitive and sustainable in light of climate change (National Water Commission 2013). A total of 500 million of AU dollars were invested in 10 years (2009-2019) to refurbish $626 \mathrm{~km}$ of delivery channels, install or upgrade 8518 outlets and structures (flumes, meters, telemetry, offtakes, automation etc.), to the benefit of more than 300 farms and of the environment (about $90^{\circ} 10^{9} 1$ per year of water savings are retained by farmers and $140 \cdot 10^{9} 1$ per year are returned to the environment). Moreover, a detailed study on the Murrumbidgee Irrigation Area (about 660,000 ha) found that about 130 extra full-time jobs were created, with positive impact on local economy that increased on average of about 20 million of AU dollars per year (Dwyer et al. 2019).

Despite the encouraging results obtained in the Australian agricultural context, the application of these flexible systems for managing gravity-driven irrigation struggles to be implemented in many other areas of the world. In the EU, only few and more limited experiences are running in some irrigation districts in France, Spain and Italy (Masseroni et al. 2018). In the case of Italy, this is due not only to the lack of public investments, but also to the historical character of the majority of the most important irrigation systems, which have been developed since the Middle Age and reached a large expansion already in the $\mathrm{XV}$ century. This determines not only a great complexity of the network topology, but also a high historical and environmental value and a deep stratification of water rights that has solidified over centuries and can hardly be scratched (Ricart and Gandolfi 2017; Ricart et al. 2019).

Given these conditions, a different strategy has been followed by the government of the Lombardy Region, which is the most important region in Italy both from the industrial and agricultural point of view, with over 7000 $\mathrm{km}^{2}$ of irrigated surfaces and close to $1000 \mathrm{~m}^{3} / \mathrm{s}$ diverted for irrigation. This strategy has been based on promoting bottom-up initiatives in the form of "information and pilot project actions" with the main purpose to attest the potential of innovative irrigation management systems at the farm and district scales, fostering the collective sharing of the modernization objectives. A total of 20 million Euros of the European Rural Development Plan were allocated during the period 2014-2020.

In this work, we examine and discuss the results obtained in one of these demonstration projects, consisting in the transition to a flexible and remote-controlled management of an irrigation diversion of the irrigation consortium Garda Chiese in northern Italy, which conveys water to an area of 150 ha. In particular, the effect of the introduction of the remote control is compared with the previous regulation, based on the manual operation of the gate according to a very simple operational rule (constant flow rate) and with an optimal regulation, which follows exactly the actual irrigation requirements of the crops in the district. The analysis is based on the flow measurements available at the district inlet over the last nine irrigation seasons (2011-2019) and includes an assessment of both the actual and potential water savings and the economic sustainability of the investment and management costs of the new gate. 


\section{Materials and methods}

\section{The case study}

The case study is represented by an irrigation district of about 150 ha (Ponte Trento irrigation district) with a single inlet, which diverts water from the Virgilio channel (the main channel deriving up to $24 \mathrm{~m}^{3} / \mathrm{s}$ from the Mincio river) at the heart of the Padana plain in northern Italy, the largest irrigated plain in the EU (Fig. 1).

The Virgilio channel is managed by the irrigation consortium Garda Chiese, which controls the irrigation supply over an area of 75,000 ha, just south from the Garda Lake, including the Ponte Trento district. The district consists of about 50 fields, of about 3 ha average area, mainly cultivated with fodder crops, where maize has been predominant since many years. Downstream of the Ponte Trento inlet the water is delivered to the fields through a dense network of unlined open ditches (about $5 \mathrm{~km}$ ) and is then applied onto the fields with surface irrigation methods, mainly border irrigation. The consortium estimates that conveyance and distribution losses in the district amount to about $30 \%$ of the flow at the district inlet, mainly due to infiltration from the ditch. The soils are quite homogeneous and their texture is predominantly loam and sandy-loam; the water table depth is of about $5 \mathrm{~m}$ from the ground surface, thus allowing to consider irrelevant the crop water uptake from the capillary fringe.
Previous to the installation of the new gate, the regulation consisted simply in a fixed opening of the gate during the whole irrigation season (from the 15th to 39th week of the year, i.e. from April to September), with an inflow that normally remained close to the target value of $360 \mathrm{l} / \mathrm{s}$. This corresponds to about $2.5 \mathrm{l} / \mathrm{s} / \mathrm{ha}$, which is the specific value of gross irrigation water requirements that has proved to be representative of the crop demand in the peak period, based on empirical evidence deriving from the long-lasting experience of the consortium. The main characteristics of the study domain are reported in Table 1.

Few gate maneuvers during irrigation season were performed manually by the consortium operators, only when the flow rate fluctuations caused by level changes in the Virgilio channel were significant (typically in dry years). We will use the acronym RR (Rigid Regulation) in the following to identify the historical management.

\section{Flexible regulation features of the inlet gate}

In 2010, the Garda Chiese irrigation consortium obtained funding from the Lombardy Region to implement a demonstration project consisting in the substitution of the manually operated gate of the Ponte Trento district with a remote-controlled gate, provided with a device for the accurate measurement of the inflow. The gate installed is a FlumeGate ${ }^{\circledR}$ automatic gate (by Rubicon Water (AU) enterprise) that is characterized by a compacted system composed by a tipping gate, a sonar flow meter, a data transmission modulus and an electronic operational system which allows a remote control
Fig. 1 Case study domain. In the picture location of diversion point on Virgilio channel and the irrigation district served by it are shown

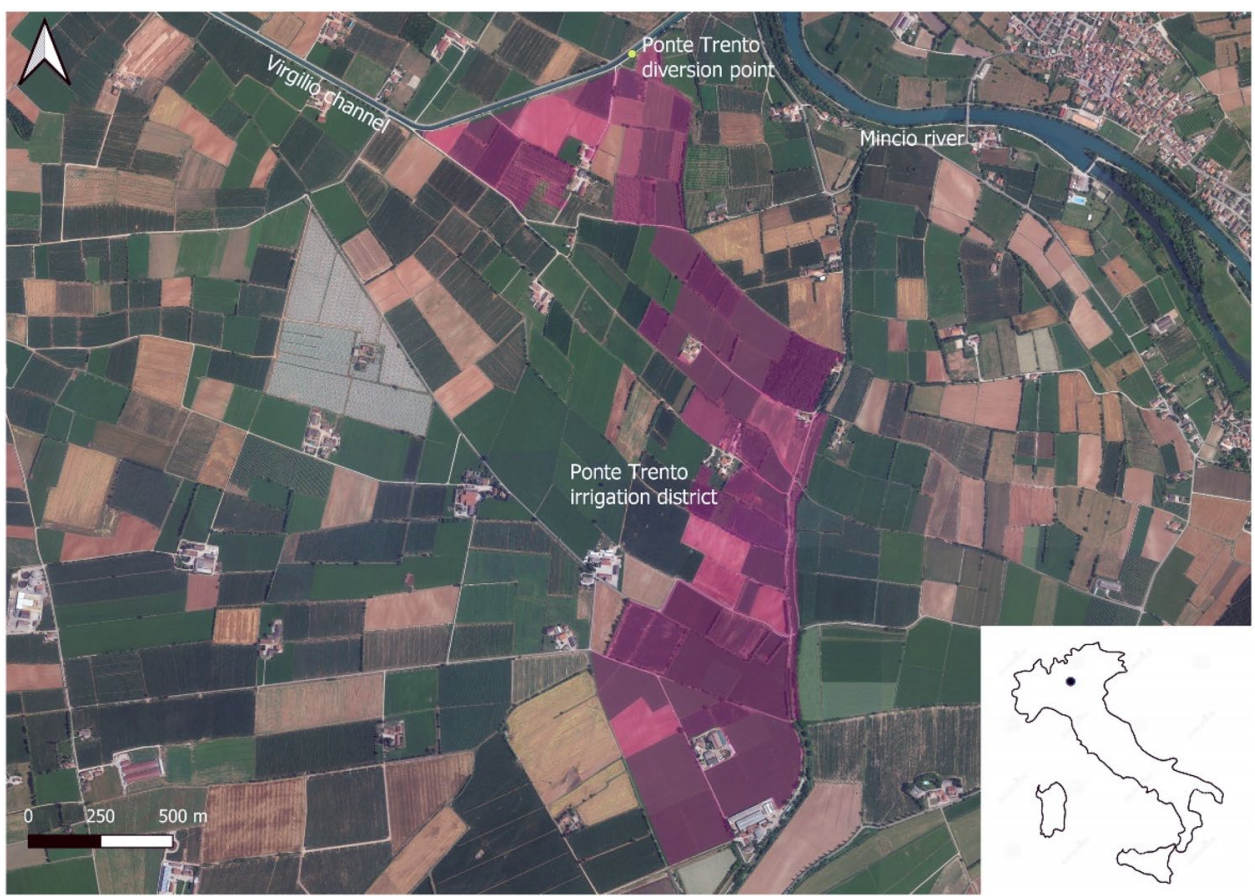


Table 1 Main characteristics of the study domain

\begin{tabular}{ll}
\hline Description & Value \\
\hline Coordinates of the Ponte Trento district & $45^{\circ} 17^{\prime} 59^{\prime \prime} \mathrm{N}-10^{\circ} 41^{\prime} 43^{\prime \prime} \mathrm{E}$ \\
Total area irrigated by Ponte Trento diversion point & $150 \mathrm{ha}$ \\
Number of filed included in the district & 50 \\
Mean dimension of the fields included in the district & $3 \mathrm{ha}$ \\
Crops cultivated in the district & Fodder crops (mainly maize) \\
$\begin{array}{l}\text { Characteristics of the irrigation water delivery network inside the } \\
\text { district }\end{array}$ & Water delivered through gravity force within unlined canal and ditches \\
$\begin{array}{l}\text { Total length of the irrigation network which delivers water from Ponte } \\
\text { Trento diversion point to each field }\end{array}$ & 5 km \\
$\begin{array}{l}\text { Irrigation season } \\
\text { Gross irrigation water requirement }\end{array}$ & $\begin{array}{l}\text { From April to September } \\
\text { Irrigation method adopted in the district }\end{array}$ \\
& $\begin{array}{c}2.5 \text { l/s/ha } \\
\text { Surface irrigation (mainly border irrigation, with irrigation depth of } \\
\text { about } 170 \text { mm for each irrigation intervention) }\end{array}$ \\
\hline
\end{tabular}

Fig. 2 The FlumeGate installed at Ponte Trento diversion point

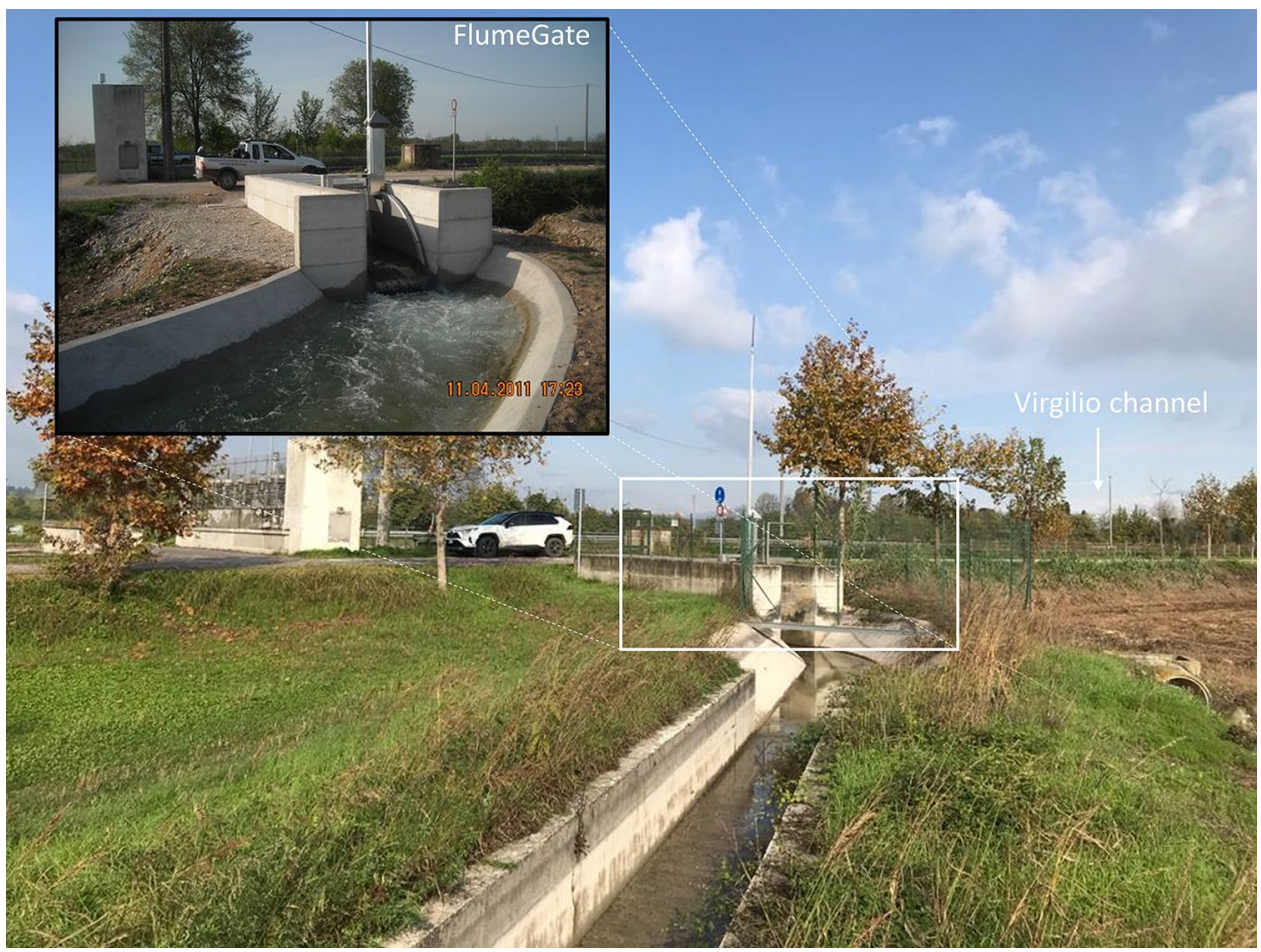

of the gate and a real time registration of system conditions (Fig. 2). All systems are self-powered with a solar panel. The gate has been operational since 2011 and inflow data are available since then.

Since the installation of the new gate, the management criteria have changed, as the remote control allowed to regulate the gate opening more promptly in response to crop water requirements and rainfall events. Specifically, the regulation policy adopted by the Consortium follows a seasonal pattern, where the inflow to the district varies during the season according to a reference irrigation demand that is slightly adapted on a weekly basis to follow the crop phenological stages of the current season. Sudden deviations from the pattern are applied only when weather forecast predicts more than $5 \mathrm{~mm}$ rainfall depth over the next $24 \mathrm{~h}$ : in this occurrence, the gate is normally closed. We will use the acronym FR (Flexible Regulation) to identify this new management policy.

We will consider also a third gate management policy, called OR (Optimal Regulation), which assumes that inflow through the gate follows exactly the actual gross irrigation requirements of the district. This policy will be 


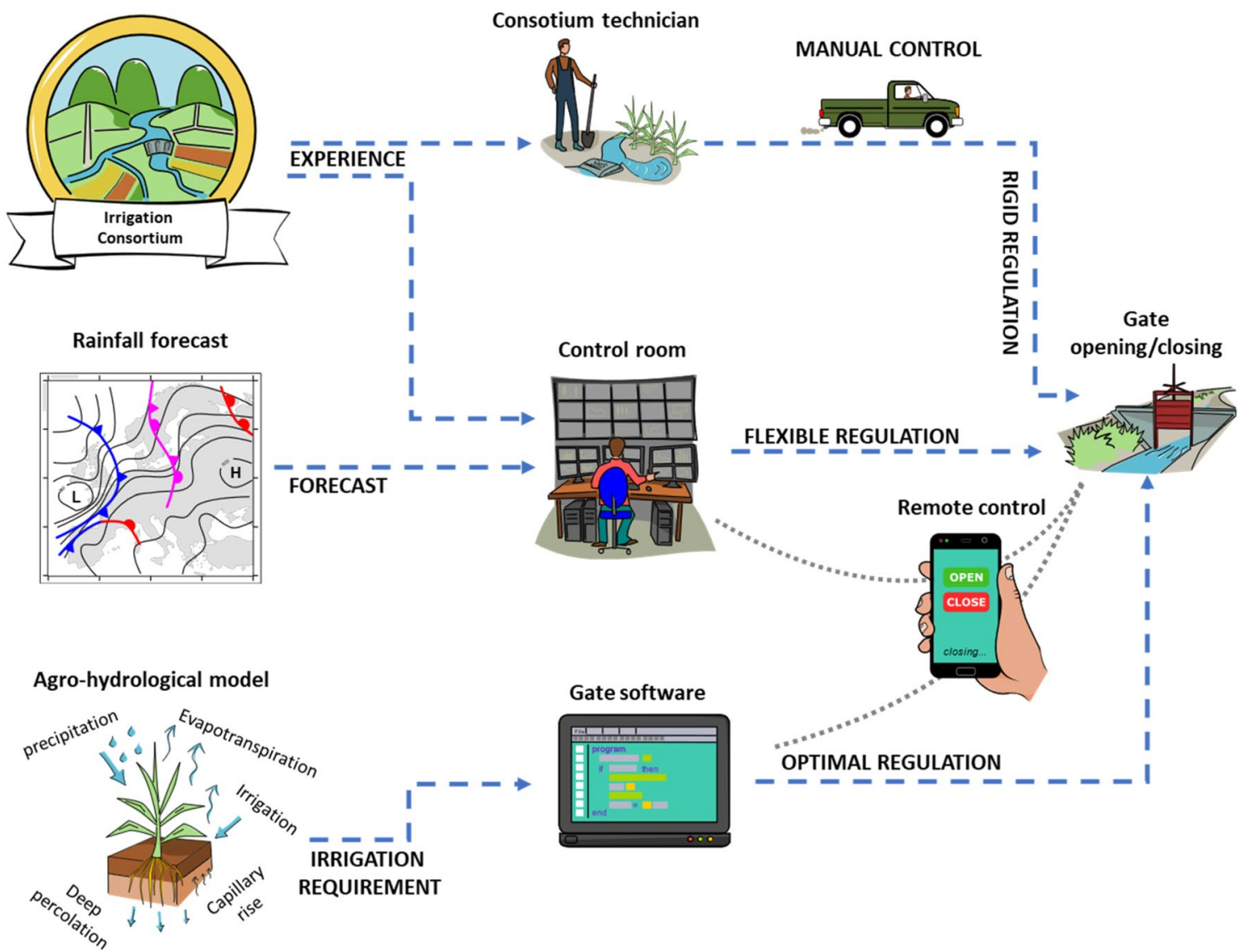

Fig. 3 Flowchart of the three approaches of gate regulation (i.e. rigid regulation, flexible regulation and optimal regulation)

used as a benchmark to assess the improvements attained with the FR compared to the OR and to quantify the further margin of progress that could be achieved. The main differences of each method of gate regulation are depicted in Fig. 3 and reported with more details in Table 2. In our analysis, the actual irrigation requirements were derived through the application of an agro-hydrological model, using the historical data of 2011-2019. Operationally, they could be estimated in real time through a combination of ground and remote sensing and simulation models (Vanino 2018; Coppola 2019).

\section{Estimation of irrigation water requirements}

The irrigation water requirements of the Ponte Trento district were estimated using the IdrAgra model (Gandolfi et al. 2010). IdrAgra is a distributed-parameter, conceptual model, which allows the simulation of the distribution of irrigation water and the computation of the daily soil-water balance. IdrAgra is the reference model used for the assessment of crop water requirements in the Lombardy region and is routinely used by the regional authority and the irrigation consortia for irrigation water use accounting and for planning

Table 2 Main characteristics of water supply provided by the three different methods of gate regulation

\begin{tabular}{ll}
\hline Gate regulation & Description \\
\hline RR-rigid regualtion & $\begin{array}{c}\text { Gate regulation is performed manually by technicians of irrigation consortium and mainly based only on their exper- } \\
\text { tise. The diverted water flow is constant during the season } \\
\text { FR—flexible regualtion } \\
\text { Gate regulation is remote-controlled by the control room of the irrigation consortium and follows a seasonal pattern. } \\
\text { The diverted water flow is slightly adapted on a weekly basis to follow the crop phenological stages of the current } \\
\text { season. Gate is closed when weather forecast predicts more than } 5 \text { mm rainfall depth over the next } 24 \mathrm{~h}\end{array}$ \\
OR-optimal regulation & $\begin{array}{c}\text { Gate regulation is completely automatized and managed through the outputs the agro-hydrological model. The } \\
\text { diverted water flow is equal to the actual irrigation water requirement of the district }\end{array}$ \\
\hline
\end{tabular}


interventions (Gandolfi et al. 2007, 2008; Vassena et al. 2012; Galelli et al. 2010).

The model includes three main modules dedicated to specific tasks: water sources, conveyance and distribution, soil-water balance. The water-balance module (Galelli et al. 2010) accounts for the spatial variability of soils and crops and of meteorological and irrigation inputs, by subdividing the basin with a regular mesh: soil and crop characteristics, meteorological inputs, and irrigation supply are homogeneous in each cell of the mesh but may vary from cell to cell. Each cell identifies a soil volume which extends from the soil surface to the lower limit of the root zone. The representation of hydrological processes is one-dimensional. The soil volume of each cell is subdivided into two layers: the top one (evaporative layer) represents the upper few centimeters of the soil, while the bottom one (transpirative layer) represents the root zone and has a time-varying depth according to the development of crop roots. Evaporation from the first layer and root water uptake for transpiration from the second layer are modelled with the FAO dual-crop coefficient approach (Allen et al. 1998). The two layers are modelled as two non-linear reservoirs in cascade, whose water retention and hydraulic conductivity curves are modeled with the Brooks and Corey (1964) and van Genuchten (1980) functions. The water percolating out of the bottom layer constitutes the recharge to the groundwater system.

\section{Dataset and model setting}

IdrAgra simulation was run over the period 2011-2019 using the daily timeseries of the relevant meteorological variables (i.e. air temperature, air humidity, solar radiation, wind velocity and rainfall), measured in a gaging station very close the Ponte Trento irrigation district, managed by the environment agency of Lombardy Region (ARPA Lombardia, https://www.arpalombardia.it/Pages/Meteorologia/ Richiesta-dati-misurati.aspx). Soil hydraulic parameters were derived from the 1:50,000 pedological map of Lombardy Region (Regione Lombardia 2011), combined with field observations of the physico-chemical characteristics of 8 soil profiles, using the Rawls and Barkensiek Pedo-Transfer Function, which were tested in a previous study in the area with fairly good results (Baroni et al. 2010; Calzolari et al. 2000). Finally, land use map was available in each year in a raster $20 \times 20 \mathrm{~m}^{2}$ format from the same regional source (SIARL; ERSAF 2019). The crop parameters (crop coefficient, leaf area index, root depth, crop height) were obtained by combining information from local studies (Facchi et al. 2013; Autorità di Bacino del Fiume Po 2003; Baldoni and Giardini 1982); Borgarello et al. 1993) and standard international references; (Huygen et al. (1997); Allen et al. (1998)). The duration of the phenological phases for each crop was adapted from Donatelli (1995) and Stockle and Nelson (1996), using local observations.

A mesh size of $250 \times 250 \mathrm{~m}^{2}$ was selected as a good compromise between discretization accuracy and detail afforded by the available information. Irrigation is automatically applied by the model to each individual cell when the water content of the rooted soil layer drops below a threshold which is fixed at the field capacity minus $70 \%$ of the Readily Available Water (RAW). The irrigation depth at each irrigation intervention is fixed at $170 \mathrm{~mm}$. This value was provided by the irrigation consortium based on extensive empirical observations on the border irrigation practiced by farmers in the area. The total weekly irrigation volume cumulated for all the cells in the district (total number of weekly irrigation applications times the irrigation depth times the cell surface area) was considered to be representative of the actual district irrigation demand, i.e. of the volume that should be allowed to flow through the gate at the district inlet under the Optimal Regulation (OR) policy.

\section{Results and discussion}

The main results of our study are summarized in Table 3 in terms of seasonal values of the main variables for each of the nine years since the inception of the FR policy. The input dataset covers a wide range of meteorological conditions, including three years with significantly above-average rainfall depth during the irrigation season (2013, 2014 and 2016) and 2 years below-average (e.g. 2011 and 2015), as shown in Table 3. It can be noticed that the precipitation depth $(\mathrm{P})$ in the wettest year (477 $\mathrm{mm}$ in 2014) is almost twofold the one in the driest (278 $\mathrm{mm}$ in 2015), both deviating almost exactly $100 \mathrm{~mm}$ from the average $(378 \mathrm{~mm}$ ). Estimated evapotranspiration, on the contrary, shows a smaller variability, as expected: values

Table 3 Precipitation $(P)$ and evapotraspiration depth (ET), specific irrigation supply with rigid gate regulation $\left(H_{\mathrm{RR}}\right)$, flexible regulation $\left(H_{\mathrm{FR}}\right)$, and optimal regulation $\left(H_{\mathrm{OR}}\right)$; all values are cumulated over the interval from the 15 th to 39 th week

\begin{tabular}{llllll}
\hline Year & $P(\mathrm{~mm})$ & $\mathrm{ET}(\mathrm{mm})$ & $H_{\mathrm{RR}}(\mathrm{mm})$ & $H_{\mathrm{FR}}(\mathrm{mm})$ & $H_{\mathrm{OR}}(\mathrm{mm})$ \\
\hline 2011 & 304 & 549 & 2500 & 1744 & 736 \\
2012 & 356 & 656 & 2500 & 1705 & 865 \\
2013 & 443 & 644 & 2500 & 903 & 621 \\
2014 & 477 & 568 & 2500 & 912 & 464 \\
2015 & 278 & 683 & 2500 & 1463 & 969 \\
2016 & 476 & 642 & 2500 & 1088 & 537 \\
2017 & 337 & 628 & 2500 & 1104 & 806 \\
2018 & 363 & 661 & 2500 & 1210 & 769 \\
2019 & 364 & 709 & 2500 & 1245 & 896 \\
Average & 378 & 638 & 2500 & 1264 & 740 \\
\hline
\end{tabular}


range from a minimum of $549 \mathrm{~mm}$ in 2011 to a maximum of $709 \mathrm{~mm}$ in 2019, with an average of $638 \mathrm{~mm}$.

Seasonal irrigation volumes supplied by the RR policy were estimated based on the constant inflow of $360 \mathrm{l} / \mathrm{s}$ and accounting for the estimated 30\% conveyance and distribution loss within the district. Therefore, the average flow available for irrigation is $250 \mathrm{l} / \mathrm{s}$, corresponding to a water depth, averaged over the whole irrigated area in the district, of $2500 \mathrm{~mm}$. This value represents obviously an upper boundary, which, however, is not far from reality in districts, in the Consorzio Garda Chiese and elsewhere, where gates are still regulated manually and very rarely during the season.

With the RR, a significant part of the irrigation volume is not actually applied to the fields, particularly during wet spells, and is drained outside the district. Indeed, the seasonal irrigation volumes drop very significantly with the FR policy, which is more reactive to rainfall events and more adherent to the actual pattern of crop water requirements. Seasonal volumes range between $903 \mathrm{~mm}$ in 2013 and $1744 \mathrm{~mm}$ in 2011, with an average of about $1264 \mathrm{~mm}$, about half of the RR value.

A further decrease of the volumes could be potentially achieved through the OR policy, i.e. by supplying exactly the residual volume of crop water requirements that is not satisfied by rainfall and that needs to be provided through irrigation to avoid crop water stress. Opposite to $H_{\mathrm{RR}}, H_{\mathrm{OR}}$ represents a lower threshold that could be reached through an optimal management exploiting a perfect knowledge of crop water requirement. Though ideal, it provides a useful reference for interpreting the efficiency of the flexible management. $H_{\mathrm{OR}}$ values range from a minimum of $464 \mathrm{~mm}$ in 2014 (the wettest agricultural season) to a maximum of $969 \mathrm{~mm}$ in 2015 (the driest one), with an average of $740 \mathrm{~mm}$, i.e. more than one-third smaller than the FR value and three times smaller than the RR.

These results are somehow consistent with previous experiences of irrigation channel modernizations, such as the one of the large-scale rehabilitation of irrigation systems in the Murray-Darling basin (NSW), where the transition from a condition, close to the RR, to the new one, close to OR, through the installation of automated controls on all channels, allowed to obtain water savings of about $65 \%$ on average (MurrayDarling basin authority 2012).

A deeper insight into the impacts of the FR and OR polices is provided by Fig. 4 that shows the weekly pattern of all variables in each year since the installation of the new gate. It can be noticed that FR tends to stick close to the RR value during the first year, deviating significantly only on the occurrence of heavy rainfalls in week 23 . OR pattern is much more variable and the gap in net water supply to the district with FR and RR is huge, both seasonally $(\mathrm{RR}=2500 \mathrm{~mm}, \mathrm{FR}=1264 \mathrm{~mm}, \mathrm{OR}=740 \mathrm{~mm}$ ) and during the peak irrigation demand period (typically weeks 22-34, when $R R=1300 \mathrm{~mm}, \mathrm{FR}=929 \mathrm{~mm}$, $\mathrm{OR}=589 \mathrm{~mm}$ ).

After the first, running-in year, that was needed to get familiar with the new device, the FR tends to become more dynamic, moving away from the RR and matching progressively better the OR, with a continuous improvement during the years, as it can be seen also Table 4 and Fig. 5. The table shows that the coefficient of determination between the weekly values of $H_{\mathrm{OR}}$ and $H_{\mathrm{FR}}$ starts very low in the first year, increases starting from the second, peaks to 0.83 in 2013 (mostly due to an anomalous wet start of the season where the gate was kept closed both by FR and OR), to stabilize then above 0.6 in the second triennium and finally above 0.8 in the last one. Figure 5 shows the time pattern of the ratios $H_{\mathrm{OR}} / H_{\mathrm{FR}}$ and $H_{\mathrm{OR}} / H_{\mathrm{RR}}$ calculated for each year, both over the whole irrigation season and over the peak irrigation demand period (weeks 22-34). It can be noticed that, as expected, the RR performs better during the peak demand period and particularly in dry seasons, while it is more interesting to observe that the FR performs in a very similar way in the two periods (except for the first two years of adaptation). Clearly, the largest water savings occur at the beginning and at the end of the season, but they are very significant also in the peak demand period.

A further interesting observation that can be derived from the analysis of Fig. 4 regards the peak weekly values of $H_{\mathrm{OR}}$ and $H_{\mathrm{FR}}$. Not surprisingly, during the peak demand period of each year, the $H_{\mathrm{FR}}$ values get very close or reach the $H_{\mathrm{RR}}$ constant inflow of $100 \mathrm{~mm} /$ week (corresponding to the net available flow of $250 \mathrm{l} / \mathrm{s}$ ) (see the gray bars and orange lines in Fig. 4). In fact, as already mentioned, the Consortium considers this value representative of the peak irrigation demand of the Ponte Trento irrigation district based on its long-lasting experience in the district management. More significant is to notice that the irrigation demands estimated by the IdrAgra model, without any parameter calibration, captures quite well this value, which is almost exactly reached in 2011 and closely approached in most of the other years. In few years (see 2013 and 2014), peak values are smaller, due to less demanding meteorological conditions.

Table 4 Determination coefficient between the weekly values of $H_{\mathrm{OR}}$ and $H_{\mathrm{FR}}$ during the irrigation season, years $2011-2019$ (from 22 to 34 week)

\begin{tabular}{llllllllll}
\hline Year & 2011 & 2012 & 2013 & 2014 & 2015 & 2016 & 2017 & 2018 & 2019 \\
\hline$R^{2}\left(H_{\mathrm{OR}}-H_{\mathrm{FR}}\right)$ & 0.16 & 0.53 & 0.83 & 0.63 & 0.71 & 0.63 & 0.91 & 0.87 & 0.84 \\
\hline
\end{tabular}



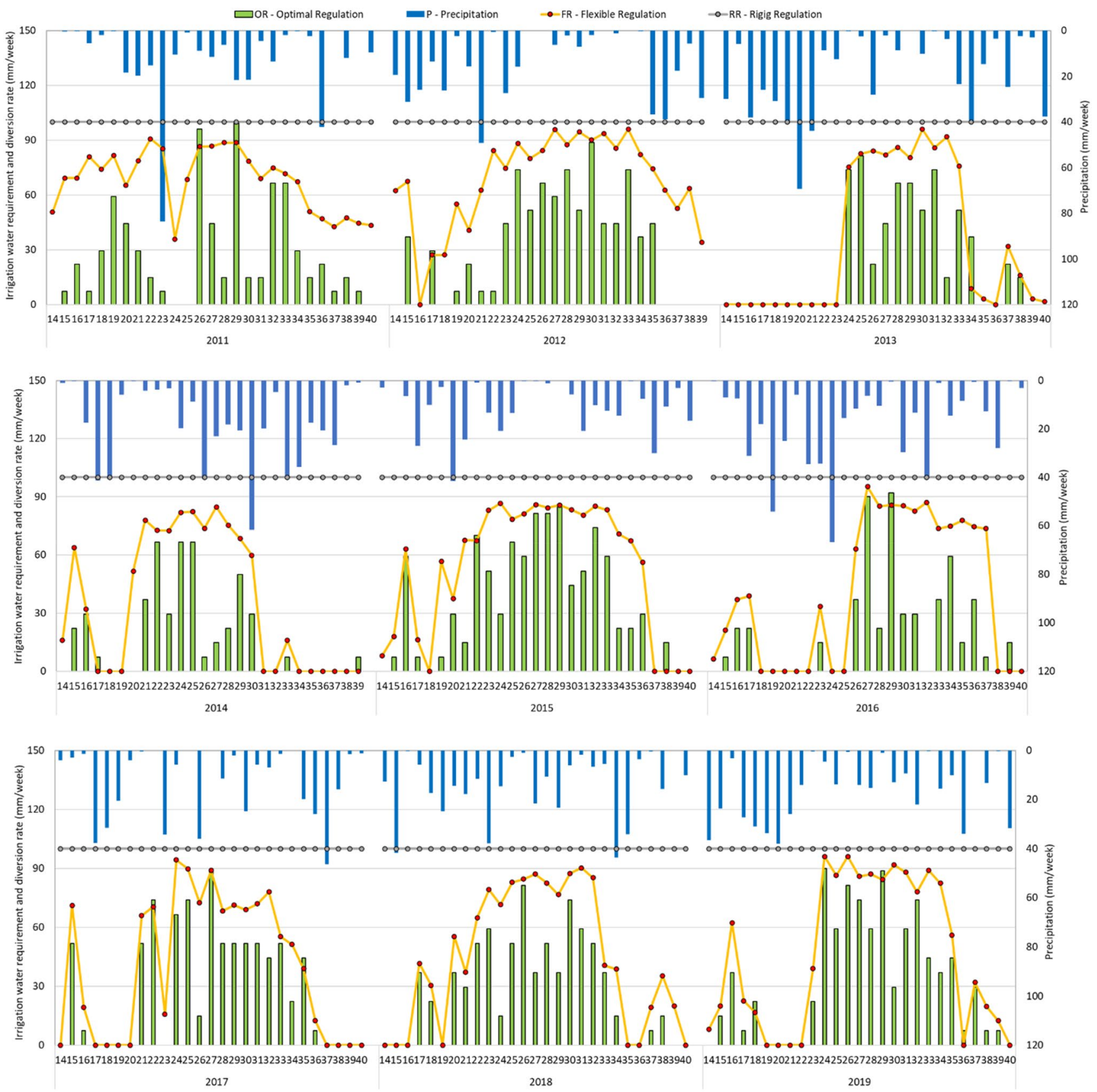

Fig. 4 Comparison between rigid regulation (RR), flexible regulation (FR) and optimal regulation from 15 to 39th week of the years 2011-2019. Precipitation is included in the figure

These results demonstrate that the FR policy has been quite rapidly assimilated by the irrigation consortium and that the transition from RR to FR has allowed significant water savings. Moreover, they show that the policy adjustments tend to match progressively more and more precisely the pattern of irrigation requirements estimated a posteriori by the IdrAgra model. If, as it seems reasonable, the skill of the consortium to manage the gate according to the actual irrigation requirements of the district has increased during the years, this provides an empirical evidence of the good ability of the model to describe the farmers' irrigation practices and to simulate the dynamics of water in the soil-crop system within the district (Fig. 5).

\section{Water saving and economic impact}

An analysis of the economic sustainability of the transition from RR to FR and, eventually, to OR was conducted. The 
Fig. 5 Inter-annual pattern of $\mathrm{OR} / \mathrm{RR}$ and $\mathrm{OR} / \mathrm{FR}$ over the whole irrigation season (solid lines) and during the peak irrigation demand period (weeks 22-34, dotted lines); precipitation depths during the same two time periods are also shown

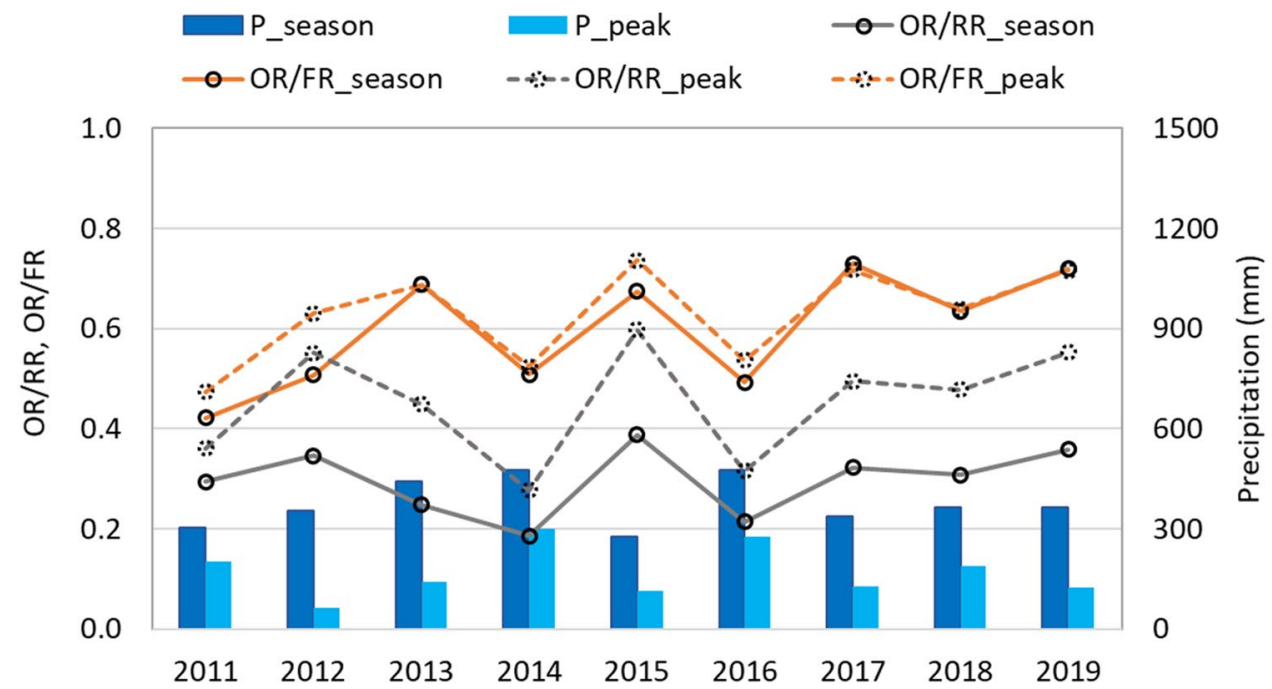

economic impact was assessed considering a volumetric water tariff of about $0.021 € / \mathrm{m}^{3}$, as found by Monaco and Sali (2014) comparing different tariffs adopted by irrigation consortia in northern Italy. The fixed costs determine $80 \%$ of this tariff, while variable costs, related to amount of water actually delivered, cover the remaining $20 \%$ (i.e. $0.0041 € / \mathrm{m}^{3}$ ).

Considering the average water-saving, about $12,000 \mathrm{~m}^{3} /$ ha/year were saved switching from RR to FR, with a further reduction of $5000 \mathrm{~m}^{3} /$ ha/year if potential transition from FR to OR is applied (see Fig. 6). The gross return is about 52 and $21 € /$ ha/year, respectively, from RR to FR and from FR to OR. If this economic saving is compared with the initial investment (about $600 € /$ ha), the investment is repaid in about 11 years for the RR to FR transition or about 8 years for the RR to OR transition.

These figures, although based on a simplified analysis, show that the adoption of automated gates, has a potential both in terms of environmental and of economic sustainability, despite the very low cost of water. Upscaling from a small district to larger areas-i.e., to the whole area where the Virgilio channel supplies irrigation, in our case study-obviously implies further investments in the network services (main channel gates and control system) that are needed to exploit the benefits of the coordinated management of a huge number of automated gates, like the one installed in the Ponte Trento district. Public incentives are therefore necessary to cover these infrastructural costs, to maintain a time of repayment of the whole intervention of about ten years. A similar incentive strategy was experimented in NSW irrigated areas, where investments were fully repaid between 5 and 15 years if application of automatic systems for gravity-fed irrigation is evaluated both at farm and irrigation district scales (Gillies and Smith 2015; Gillies et al. 2010).
Fig. 6 Water and economic saving from RR to FR and from FR to $\mathrm{OR}$ transition processes

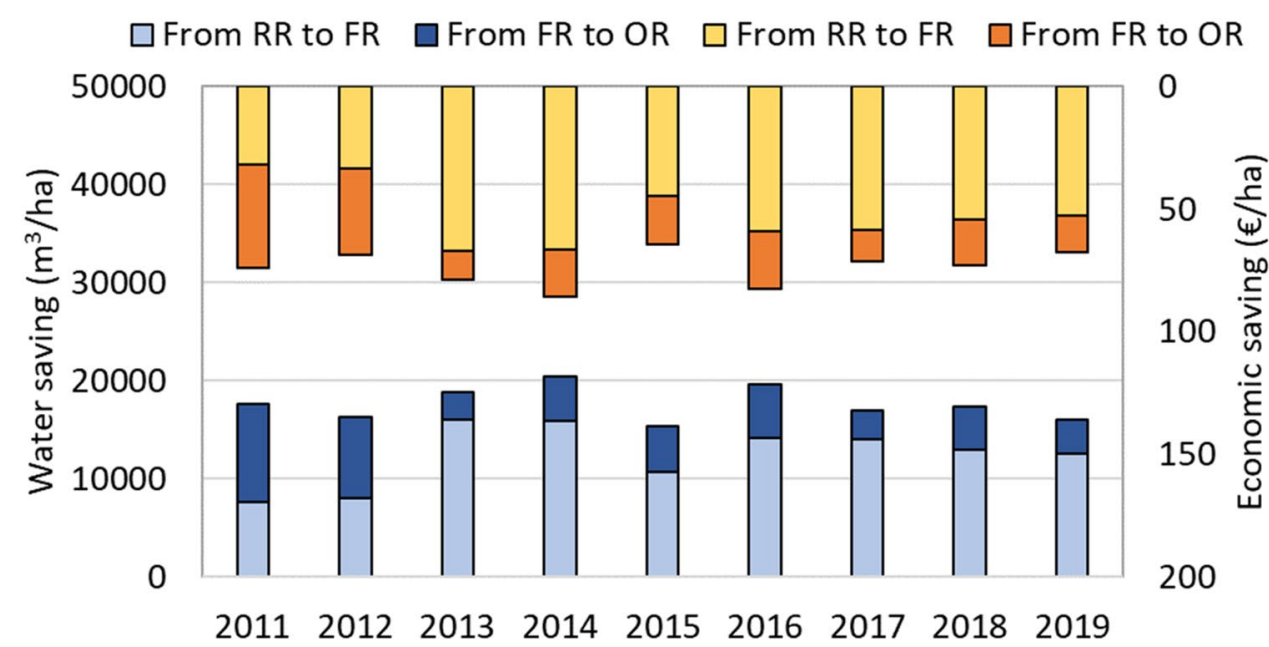




\section{Conclusion}

We examined the effects of the transition from a rigid regulation (RR) policy of the inflow to a 150 ha irrigated district in the Padana plain (Italy) to a more flexible regulation (FR) policy, allowed by the installation of an automated, remotely controlled gate at the district inlet. The analysis of nine years of daily measurements of the inflow shows that the FR adoption halves the seasonal water supply to the district, compared to the RR. The water savings are less pronounced if only the peak irrigation demand period is considered, but they remain very significant (about 30\%). Additional savings can be achieved if the empirical criteria adopted by the irrigation consortium to manage the gate are complemented with estimates of the actual crop water requirements provided by an agro-hydrological model. Assuming a perfect knowledge of the district irrigation requirements (optimal regulation, OR), the average seasonal water savings reach $70 \%$ of the RR volume and $40 \%$ of the FR one. Again, these savings are smaller over the peak demand period, but still very significant.

A remarkable observation is that the FR becomes more dynamic already after the first year and progressively in the following ones, moving away from the RR and matching the OR increasingly well. This demonstrates that the adaptation of the management to the new technology is quite rapid and provides empirical evidence of the good ability of the agrohydrological model to describe the farmers' irrigation practices and to simulate with sufficient accuracy the dynamics of water in the soil-crop system at the district scale.

Finally, a preliminary economic analysis shows that the time of repayment of the automated gate is about ten years, based on the local cost of irrigation water.

These results can be considered very satisfactory in view of the framework in which the transition from RR to FR was realized. In fact, the automated gate was co-funded by the regional government as a demonstration project to foster innovation in water management in the Lombardy region. Our analysis confirms that there is a large potential for the application of these devices, both in terms of environmental and of economic sustainability. However, upscaling from a small district to larger irrigation systems-e.g., to the whole area where the Virgilio channel supplies irrigation-has a number of implications in terms management, requiring further investments in the network services (installation of automated gates in the main channel and implementation of an integrated control system). These will need the support of public incentives to cover at least part of these infrastructural costs, to maintain the time of repayment of the whole intervention in the order of 10 years.

Acknowledgements The authors are deeply grateful to Dr. Paolo Magri and Dr. Chiara Salami of the Garda Chiese irrigation consortium for providing data and information for the Ponte Trento district and for their feedback on our results. This work was developed in the context of the IRRIGATE project- - Towards an intelligent management of gravity-fed irrigation through the combination of irrigation water requirement models and automatic system of water deliveries" funded by Regione Lombardia (Regional Developing Plans 2014-2020 n. 1.2.01 - Information and pilot project actions) and INCIPIT projectINtegrated Computer modeling and monitoring for Irrigation Planning in Italy, funded by the Italian Ministry of Education, University and Research under the programme PRIN 2017.

Funding Open Access funding provided by Università degli Studi di Milano.

Open Access This article is licensed under a Creative Commons Attribution 4.0 International License, which permits use, sharing, adaptation, distribution and reproduction in any medium or format, as long as you give appropriate credit to the original author(s) and the source, provide a link to the Creative Commons licence, and indicate if changes were made. The images or other third party material in this article are included in the article's Creative Commons licence, unless indicated otherwise in a credit line to the material. If material is not included in the article's Creative Commons licence and your intended use is not permitted by statutory regulation or exceeds the permitted use, you will need to obtain permission directly from the copyright holder. To view a copy of this licence, visit http://creativecommons.org/licenses/by/4.0/.

\section{References}

Allen R, Pereira LS, Raes D, Smith M (1998) Crop evapotranspiration: guidelines for computing crop water requirements, FAO Irrigation and Drainage Paper 56, FAO, Rome

Autorità di Bacino del Fiume Po (2003) Studio di fattibilitàdellasistemazioneidraulicadeifiumiAdda, Serio e Oglio [Feasibility study of hydraulic settlement of the Adda, Serio and Oglio rivers]. Autorità di Bacino del Fiume Po, Parma

Baldoni R, Giardini L (1982) Coltivazionierbacee [Herbaceous cultivation]. Patron, Bologna

Baroni G, Facchi A, Gandolfi C, Ortuani B, Horeschi D, van Dam JC (2010) Uncertainty in the determination of soil hydraulic parameters and its influence on the performance of two hydrological models of different complexity. Hydrol Earth SystSci 14:251-270

Bhat SP, Hirekhan SR (2015) Automation of water discharge process at canals. In: 2015 International conference on Applied and Theoretical computing and communication Technology (iCATccT). IEEE, pp 609-613

Bonet E, Gómez M, Yubero MT, Fernández-Francos J (2019) GoRoSoBo simplified: an accurate feedback control algorithm in real time for irrigation canals. J Hydroinf 21(6):945-961

Borgarello M, Catenacci G, Cavicchioli C, Parini S (1993) Indagini sulla deposizione secca [Studies on dry deposition]. Rapporto CISE-SAA-93-042, CISE, Milan, Italy

Brooks RH, Corey AT (1964) Hydraulic properties of porous media. Hydrology paper no. 3, Colorado State University, Fort Collins, $\mathrm{CO}$

Calzolari C, Ungaro F, Busono E, Sanchiz PS (2000) Dinamica degli orizzonti superficiali e stima della conducibilità satura [Dynamics of shallow horizons and estimate of the saturated conductivity]. Rapporto no. 8.1, CNR IGES, Florence, Italy

Coppola A, Dragonetti G, Sengouga A, Lamaddalena N, Comegna A, Basile A, Noviello N, Nardella L (2019) Identifying optimal irrigation water needs at district scale by using a physically 
based agro-hydrological model. Aqua 11(4):841. https://doi. org/10.3390/w11040841

Donatelli M (1995) Sisteminellagestioneintegratadellecolture [Systems of integrated management of cultivations]. Pubblicazionespecial edell'IstitutoSperimentaleAgronomico ISA-Sezione di Modena, Modena, Italy

Facchi A, Gharsallah O, Corbari C, Masseroni D, Mancini M, Gandolfi C (2013) Determination of maize crop coefficients in humid climate regime using the eddy covariance technique. Agric Water Manag 130:131-141

Monaco Federica, Sali Guido (2014) L'acqua ad uso irriguo in un distretto risicolo: valutazione economica in differenti condizioni di pricing. Agriregioneuropa $10 \mathrm{n}^{\circ} 36$

Galelli S, Gandolfi C, Soncini-Sessa R, Agostani D (2010) Building a metamodel of an irrigation district distributed-parameter model. Agric Water Manag 97:187-200

Gandolfi C, Ponzini G, Giudici M, Ortuani B, Facchi A, Vassena C, Durante C, Varola L, Rienzner M, Agostani D (2007) Realizzazione di un modellopreliminare del flussoidriconelsistemaacquiferodellaprovincia di Cremona [Realization of a preliminary groundwater flow model of the Province of Cremona]. UniversitàdegliStudi di Milano, Milan

Gandolfi C, Ponzini G, Giudici M, Ortuani B, Facchi A, Togni L, Rienzner M, Agostani D (2008) Sviluppo di un modello preliminare del bilancio idrologico dei suoli agrari e del flusso idrico del sistema acquifero della pianura bergamasca [Development of a preliminary model of the water balance in cultivated soils and of groundwater in the Bergamo plain]. Università degli Studi di Milano, Milan, Italy

Gandolfi C, Agostani D, Facchi A, Ortuani B, Rienzner M (2010) Modello e codice di calcoloIdrAgra [IdrAgra model and computer code]. UniversitàdegliStudi di Milano, Milan

García IF, Díaz JR, Poyato EC, Montesinos P, Berbel J (2014) Effects of modernization and medium term perspectives on water and energy use in irrigation districts. AgricSyst 131:56-63

García IF, Montesinos P, Poyato EC, Díaz JR (2016) Energy cost optimization in pressurized irrigation networks. IrrigSci 34(1):1-13

Gavan D, Matthew C, Rod C (2019) Economic effects of the Commonwealth water recovery programs in the Murrumbidgee Irrigation Area. Marsden Jacob Associates Pty Ltd 2017

Gillies MH, Smith RJ (2015) SISCO: surface irrigation calibration and optimisation. IrrigSci 33:339-355

Gillies MH, Smith RJ, Williamson B, Shanahan M (2010) Improving performance of bay irrigation through higher flow rates. In: Australian Irrigation Conference and Exhibition, 8-10 June, Sydney, Australia

Haie N, Keller AA (2008) Effective Efficiency as a Tool for Sustainable Water Resources Management. J Am Water Resour As 44(4):961-968

Huygen JC, van Dam JC, Kroes JG, Wesseling JG (1997) SWAP 2.0: input and output manual. Technical document, WAU and DLOStaring Centrum, Wageningen, The Netherlands

Khatavkar P, Mays LW (2020) Real-time operation of water-supply canal systems under limited electrical power and/or water availability. J Water Resour Plan Manag 146(4):04020012

Kong L, Lei X, Wang M, Shang Y, Quan J, Wang H (2019) A regulation algorithm for automatic control of canal systems under emergency conditions. Irrig Drain 68(4):646-656

Regione Lombardia (2011) Geographical data download portal. http:// www.cartografia.regione.lombardia.it/rlregisdownload/. Cited 1 December 2011.Resour. Assoc. 2008, 44, 961-968. [CrossRef]

Masseroni D, Ricart S, De Cartagena FR, Monserrat J, Gonçalves JM, De Lima I et al (2017) Prospects for improving gravity-fed surface irrigation systems in Mediterranean European contexts. Water 9(1):20
Masseroni D, Moller P, Tyrell R, Romani M, Lasagna A, Sali G et al (2018) Evaluating performances of the first automatic system for paddy irrigation in Europe. Agric Water Manag 201:58-69

Mateos L (2008) Identifying a new paradigm for assessing irrigation system performance. IrrigSci 27:25-34

Murray-Darling basin authority (2012) Hydrological modelling to inform the proposed basin plan. Published by Murray-Darling basin authority. ISBN: 978-1-922068-23-1

National Water Commission (2013) Water programs across the Murray-Darling Basin, retrieved May 25, 2020. www.agricultur e.gov.au/water/mdb/programs/basin-wide

Pachauri RK, Allen MR, Barros VR, Broome J, Cramer W, Christ R, Church JA, Clarke L, Dahe Q, Dasgupta P, Dubash NK, Edenhofer O, Elgizouli I, Field CB, Forster P, Friedlingstein P, Fuglestvedt J, Gomez-Echeverri L, Hallegatte S, et al (2014) Climate change 2014: Synthesis Report. Contribution of Working Groups I, II and III to the Fifth Assessment Report of the Intergovernmental Panel on Climate Change (RK Pachauri, L Meyer, A c. Di). IPCC. https://epic.awi.de/id/eprint/37530/

Perry C, Steduto P, Karajeh F (2017) Does improved irrigation technology save water? A review of the evidence. Food and Agriculture Organization of the United Nations, Cairo, 42

Ricart S, Gandolfi C (2017) Balancing irrigation multifunctionality based on key stakeholders' attitudes: lessons learned from the Muzza system, Italy. Land Use Policy 69:461-473

Ricart S, Rico A, Kirk N, Bülow F, Ribas-Palom A, Pavón D (2019) How to improve water governance in multifunctional irrigation systems? Balancing stakeholder engagement in hydrosocial territories. Int J Water Resour Dev 35(3):491-524

Rodríguez Díaz JA, Camacho Poyato E, Blanco Pérez M (2011) Evaluation of water and energy use in pressurized irrigation networks in Southern Spain. J Irrig Drain Eng 137(10):644-650

Smith RJ, Uddin JM, Gillies MH, Moller P, Clurey K (2016) Evaluating the performance of automated bay irrigation. IrrigSci 34(3): 175-185

Stockle CO, Nelson RL (1996) Cropsyst User's manual (Version 2.0). Biological Systems Engineering Dept., Washington State University, Pullman, WA

Tarjuelo JM, Rodríguez DíazRodriguez-Diaz JA, Abadía R, Camacho E, Rocamora C, Moreno MA (2015) Efficient water and energy use in irrigation modernization: lessons from Spanish case studies. Agric Water Manag 162:67-77

USDA-SCS (US Department of Agriculture-Soil Conservation Service) (1972) National engineering handbook, part 630, Hydrology, section 4, US Government Printing Office, Washington, DC

Van Genuchten MT (1980) A closed-form equation for predicting the hydraulic conductivity of unsaturated soils. Soil SciSoc Am J 44:892-898

Vanino S, Nino P, De Michele C, Bolognesi SF, D’Urso G, Di Bene C, Napoli R (2018) Capability of Sentinel-2 data for estimating maximum evapotranspiration and irrigation requirements for tomato crop in Central Italy. Remote Sens. Environ 215:452-470

Vassena C, Rienzner M, Ponzini G, Giudici M, Gandolfi C, Durante C, Agostani D (2012) Modeling water resources of a highly irrigated alluvial plain (Italy): calibrating soil and groundwater models. Hydrogeol J 20(3):449-467

Zheng Z, Wang Z, Zhao J, Zheng H (2019) Constrained model predictive control algorithm for cascaded irrigation canals. J Irrig Drain Eng 145(6):04019009

Publisher's Note Springer Nature remains neutral with regard to jurisdictional claims in published maps and institutional affiliations. 